\title{
The correlation between the appearance of non-melanocytic skin tumors and exposure to UV radiation
}

\author{
Corelaţia dintre apariţia tumorilor cutanate nonmelanocitare și \\ expunerea la radiații UV
}

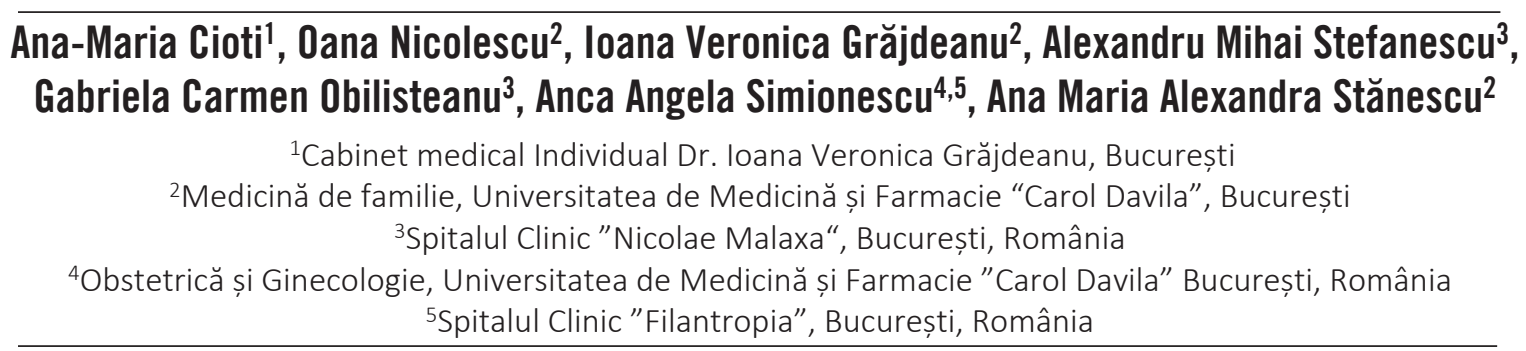

\begin{abstract}
Introduction. In the last 30 years, the incidence of non-melanocytic skin tumors (NMRTs) has increased alarmingly. The most common subtype of TCNM is basal cell carcinoma followed by squamous cell carcinoma.

Material and method. This retrospective study was performed on a group of 140 patients. Patients diagnosed with C44 nonmelanocytic malignancy according to ICD-10 were included in the study.

Results. Of the 140 patients, $118(84 \%)$ received the presumptive diagnosis of CBC and $17(12 \%)$ the diagnosis of CSC. Histopathological examination confirmed the diagnosis of CBC in $76 \%$ of cases and that of CSC in $58 \%$ of cases. Regarding the number of lesions, cases with a single lesion predominate $(94 \%)$. In terms of clinical form, the most common type of basal cell carcinoma in the study group was $75 \%$ nodular carcinoma.

Conclusions. There is a need for more studies for the application of prevention and proper management from the family doctor to the specialist.
\end{abstract}

Keywords: skin cancer, basal cell carcinoma, squamous cell carcinoma, UV radiation

\section{REZUMAT}

Introducere. În ultimii 30 de ani, incidenta tumorilor cutanate nonmelanocitare (TCNM) a cunoscut o creștere alarmantă. Cel mai frecvent subtip de TCNM este carcinomul bazocelular, urmat de carcinomul scuamocelular.

Material şi metodă. Acest studiu retrospectiv a fost realizat pe un lot de 140 pacienți. Au fost incluși în studiu pacienții cu diagnostic de neoplasm malign nonmelanocitar C44 conform ICD-10.

Rezultate. Dintre cei 140 de pacienți, 118 (84\%) au primit diagnosticul prezumtiv de CBC și 17 (12\%) pe cel de CSC. Examenul histopatologic a confirmat diagnosticul de CBC în 76\% dintre cazuri și pe cel de CSC în $58 \%$ dintre cazuri. În ceea ce privește numărul de leziuni, au predominat cazurile cu o singură leziune $(94 \%)$. Din punctul de vedere al formei clinice, cel mai întâlnit tip de carcinom bazocelular în lotul studiat a fost cel nodular, în procent de $75 \%$.

Concluzii. Se evidențiază necesitatea mai multor studii pentru aplicarea unei prevenții și a unui management corespunzător începând de la medicul de familie până la specialist.

Cuvinte cheie: cancer de piele, carcinom bazocelular, carcinom spinocelular, radiații UV

\section{INTRODUCERE}

Pielea este expusă constant mediului oxidativ, în mod special radiațiilor ultraviolete. În 2009, în- treg spectrul de radiații solare a fost catalogat drept carcinogen pentru oameni de către Organizația Mondială a Sănătății, inclusiv bronzatul artificial, ca agent carcinogen uman de clasa I, la acelaşi ni- 
vel cu radiaţiile solare fiind substanțe precum azbestul, arsenicul, hidrocarburile (1). Expunerea solară cronică determină fotoîmbãtrânire și fotocarcinogeneză, reprezentând cel mai important factor de risc ambiental atât pentru apariția melanomului, cât și a tumorilor cutanate nonmelanocitare (TCNM). Tumorile cutanate nonmelanocitare sunt cel mai frecvent diagnosticate cancere la nivel mondial (2).

Tumorile maligne reprezintă una dintre cele mai importante probleme medicale actuale atât prin procentul crescut de mortalitate, cât și prin impactul socioeconomic pe care acestea îl au asupra vieții individului cât și a societății. Dintre aceste tumori, cancerul de piele reprezintă aproximativ $15-20 \%$ din total, este cel mai frecvent tip de cancer, cunoscând o creștere a incidenţei în ultimele decenii. Anual, incidența cancerelor cutanate depășește incidența cumulată a cancerelor mamare, prostatice, pulmonare și colonice (2).

În prezent, 1 la fiecare 3 cazuri de cancer diagnosticat este un cancer de piele, între 2 și 3 milioane de pacienți sunt diagnosticați anual la nivel mondial cu tumori cutanate nonmelanocitare (3). În SUA, aproximativ 5 milioane de persoane sunt tratate în fiecare an pentru cancer cutanat, costul anual estimativ depășind suma de 8 miliarde de dolari (4).

Carcinomul bazocelular, considerat cel mai frecvent cancer de piele la om, este răspunzător pentru mai puțin de $0,1 \%$ dintre decesele pacienților cauzate de cancer. CBC apar de obicei pe pielea expusă cronic la soare, cresc lent și metastazează foarte $\operatorname{rar}(0,028-0,55 \%)(5)$.

Keratoza actinică (KA) este, de departe, cea mai frecventă leziune cu potențial malign ce se poate dezvolta pe piele. Apare ca urmare a expunerii solare îndelungate și repetate și poate progresa către carcinom spinocelular invaziv (6).

Carcinomul spinocelular (CSC) este al doilea cel mai frecvent tip de tumoră cutanată nonmelanocitară după carcinomul bazocelular (CBC). Deși majoritatea CSC sunt curabile, studiile au arătat că până la $14 \%$ pot metastaza, iar dintre acestea $40 \%$ se soldează cu deces, fiind responsabile de majoritatea deceselor cauzate de tumorile cutanate nonmelanocitare (2).

Lucrarea de față are drept scop înțelegerea conexiunii dintre expunerea la radiații UV și dezvoltarea în timp a unei forme de tumori cutanate nonmelanocitare.

\section{MATERIAL ŞI METODE}

Acest studiu retrospectiv a fost realizat pe un lot de 140 pacienți in cadrul Clinicii de Dermatolo- gie II a Spitalului Clinic Colentina și a avut perioada de desfășurare de 1 an. Au fost incluși în studiu pacientii cu diagnostic de neoplasm malign nonmelanocitar C44 conform ICD-10.

Datele au fost extrase din arhiva digitală a spitalului, fiind luate în considerare pentru analiza retrospectivă aspectele epidemiologie, clinice și paraclinice. Examenul histopatologic a fost corelat cu evaluarea clinică făcută la prezentare. Pentru realizarea acestui studiu, s-au avut în vedere parametrii epidemiologici (sex, vârsta, luna prezentării, mediu de proveniență, județul de rezidență), parametrii clinici (diagnostic clinic, formă clinică, localizare, numărul de leziuni la prezentare) și parametrii paraclinici (rezultatul examenului histopatologic).

Pentru diferentierea carcinoamelor spinocelulare s-a utilizat clasificarea OMS: G1 -carcinom spinocelular bine diferenţiat: G2 - carcinom spinocelular moderat diferenţiat: G3 - carcinom spinocelular puţin diferenţiat: G4 - carcinom spinocelular nediferenţiat. Prelucrarea statistică s-a efectuat utilizând programele Microsoft Office Excel, Microsoft Office Word şi Microsoft Office Picture Manager.

\section{REZULTATE}

Dintre cei 140 de pacienți, 118 (84\%) au primit diagnosticul prezumtiv de CBC și 17 (12\%) pe cel de CSC. În 4\% dintre cazuri, examinarea clinică nu a adus suficiente date care să îndrume diagnosticul spre unul dintre tipurile de carcinom cutanat nonmelanocitar. Se observă în lotul studiat o predominanță marcată a numărului de cazuri de $\mathrm{CBC}$, care este în concordanță cu datele din literatură referitoare la incidența cazurilor de $\mathrm{CBC}$ comparativ cu cele de CSC (Figura 1).

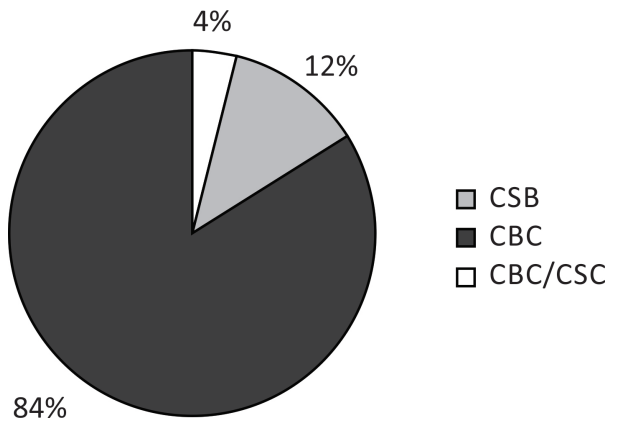

FIGURA 1. Repartiția cazurilor în funcție de diagnosticul clinic

Examenul histopatologic a confirmat diagnosticul de CBC în 76\% dintre cazuri și pe cel de CSC în $58 \%$ dintre cazuri. Iniţial, 8 pacienți au fost suspicionați clinic de CBC, dovedindu-se a fi CSC după realizarea examenului HP. 
TABEL 1. Rezultatele examenului HP în cazurile unde diagnosticul clinic $C B C$ nu se confirmă histopatologic

\begin{tabular}{|l|l|c|}
\hline $\begin{array}{l}\text { Diagnostic } \\
\text { clinic }\end{array}$ & Diagnostic HP & $\begin{array}{c}\text { Număr } \\
\text { de cazuri }\end{array}$ \\
\hline$C B C$ & Keratoză actinică & 4 \\
\hline$C B C$ & Keratoză seboreică & 3 \\
\hline$C B C$ & Keratoacantom & 2 \\
\hline$C B C$ & Porom & 2 \\
\hline$C B C$ & $\begin{array}{l}\text { Hiperplazie epidermică cu inflamație } \\
\text { lichenoidă şi perivasculară }\end{array}$ & 2 \\
\hline$C B C$ & $\begin{array}{l}\text { Adenom anexial cu diferențiere ecrină } \\
\text { si foliculară }\end{array}$ & 1 \\
\hline $\begin{array}{l}C B C \\
\text { recidivant }\end{array}$ & Fibroză cicatriceală dermică & 1 \\
\hline$C B C$ & Condrodermatitis nodular helicis & 1 \\
\hline$C S C$ & $\begin{array}{l}\text { Carcinom sebaceos grad I dezvoltat } \\
\text { pe nev Jadassohn }\end{array}$ & 1 \\
\hline
\end{tabular}

Vârsta pacienților a fost cuprinsă între 37 și 94 ani, cu o medie de vârstă de 73,07 $\pm 12,09$ ani. Frecvența carcinoamelor crește o dată cu vârsta, incidența maximă fiind la grupa de vârstă 70-79 ani. Următoarea grupă de vârstă, ca frecvență, este cea de 80-89 ani.

În ceea ce privește vârsta pacienților diagnosticați cu carcinom bazocelular, extremele de vârsta au fost reprezentate de 37 ani, respectiv 94 ani, pacienții având o medie de vârstă de 71,90 \pm 11,9 ani. Prevalența crește o dată cu vârsta, observându-se doar 5 cazuri la pacienții cu vârsta cuprinsă în intervalul 35-49 ani.

Referitor la vârsta pacienților diagnosticați cu carcinom spinocelular, extremele de vârsta au fost reprezentate de 60 ani, respectiv 92 ani, pacienții având o medie de vârstă de 80,09 \pm 9,99 ani. În intervalul de vârstă 70-79 ani, se regăsesc 3 cazuri $(13,6 \%)$, ca și în intervalul 90-100 (13,6\%).
Distribuția pe sexe arată o frecvență mai mare a cazurilor de carcinom bazocelular la sexul masculin $(55 \%)$ în comparație cu cel feminin (45\%), iar în rândul cazurilor de carcinom spinocelular numărul bărbaților (68\%) depășește numărul femeilor $(32 \%)$.

Cei mai mulți pacienți, 71 la număr $(75 \%)$, locuiesc în mediul urban, în timp ce din mediul rural provin 23 de pacienți $(25 \%)$.

O frecvență crescută a prezentării la spital s-a înregistrat şi în lunile aprilie $(\mathrm{n}=18)$, aeptembrie $(n=15)$, mai $(n=14)$ şi februarie $(n=14)$. Cel mai mic număr de pacienți s-a înregistrat în luna decembrie.

București este, de departe, județul din care au provenit cei mai mulți pacienți din lotul studiat (n =96), urmat de Ilfov $(n=10)$, Ialomița $(n=6)$ și Călărași $(n=6)$.

În ceea ce privește numărul de leziuni, au predominat cazurile cu o singură leziune (94\%). Există 6 cazuri cu 2 leziuni (4\%), în timp ce leziuni multiple care îmbracă aspectul de epiteliomatoză au fost prezente la 3 pacienți (2\%).

În lotul studiat, carcinoamele s-au localizat cel mai frecvent la nivelul capului, următoarea localizare fiind trunchiul, apoi membrele. După cum se observă în figura 5, procentul maxim de leziuni de carcinom bazocelular, $74 \%$, este situat la nivelul capului, 24\% la nivelul trunchiului și 2\% la nivelul membrelor. În ceea ce privește carcinoamele spinocelulare, cele mai multe leziuni, în proporție de $86 \%$, au fost localizate la nivelul capului, $9 \%$ la nivelul membrelor și 5\% la nivelul trunchiului.

Cele mai multe leziuni de carcinom bazocelular de la nivelul extremității cefalice s-au situat la ni-

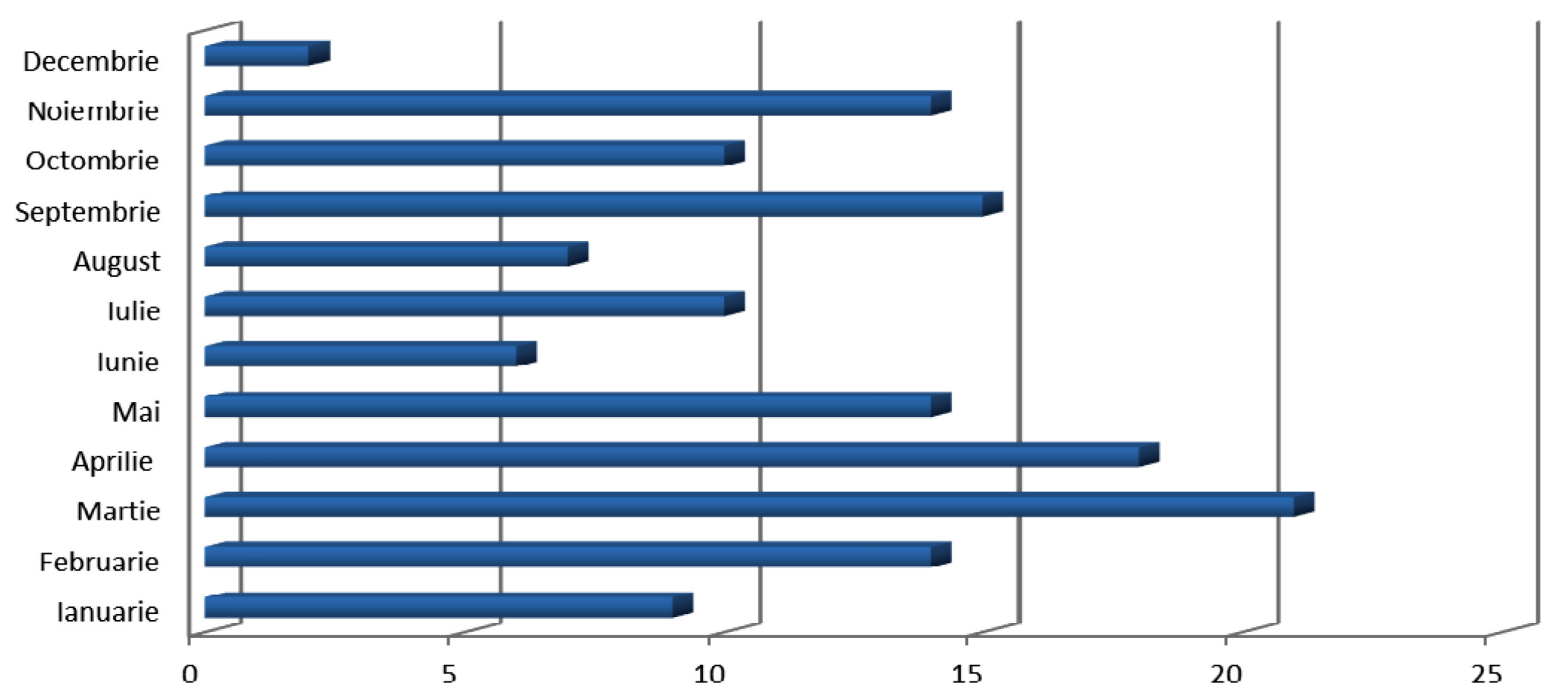

FIGURA 2. Repartiția cazurilor în funcție de luna prezentării la spital 


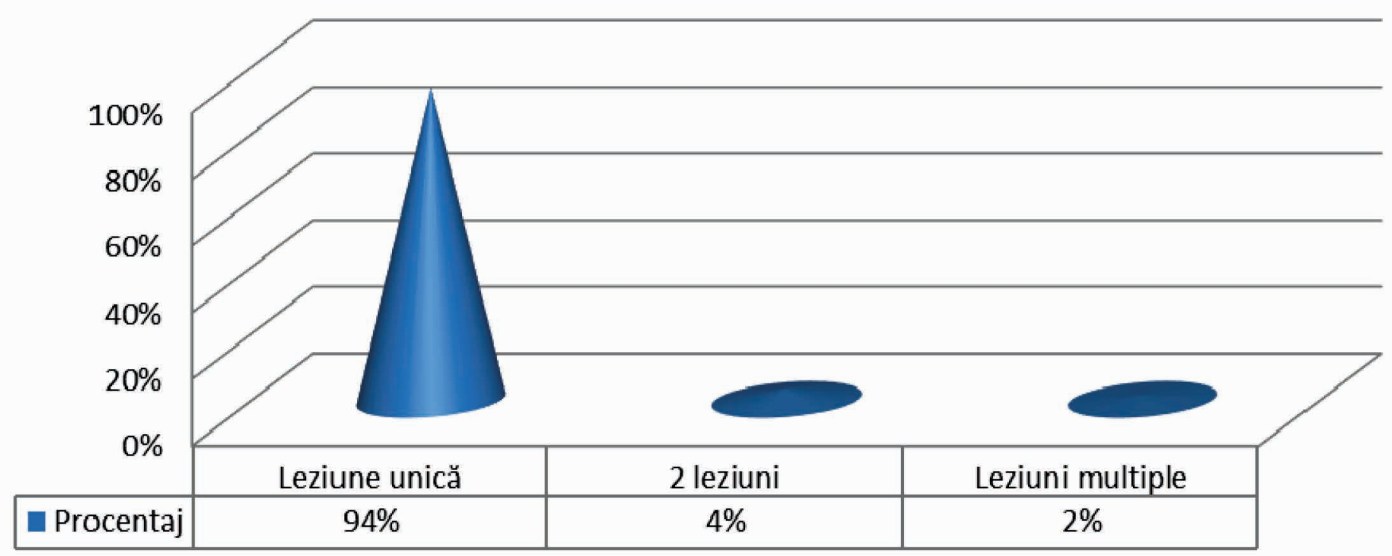

FIGURA 3. Repartiția cazurilor în funcție de numărul de leziuni

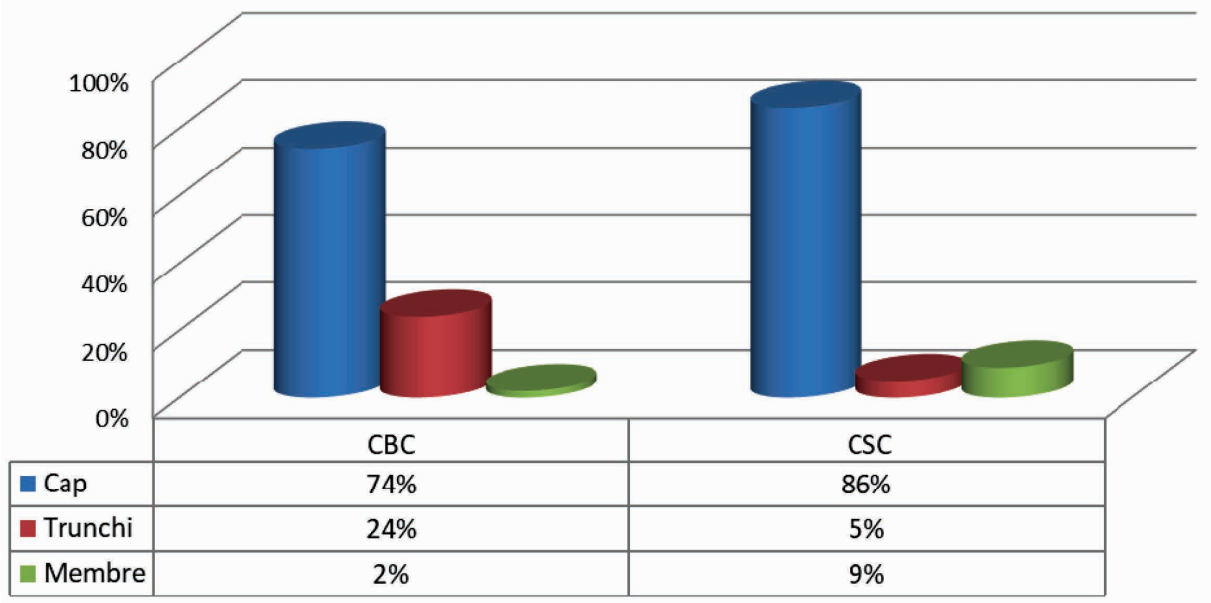

FIGURA 4. Repartiția cazurilor în funcție de localizarea topografică a leziunilor şi tipul de carcinom cutanat

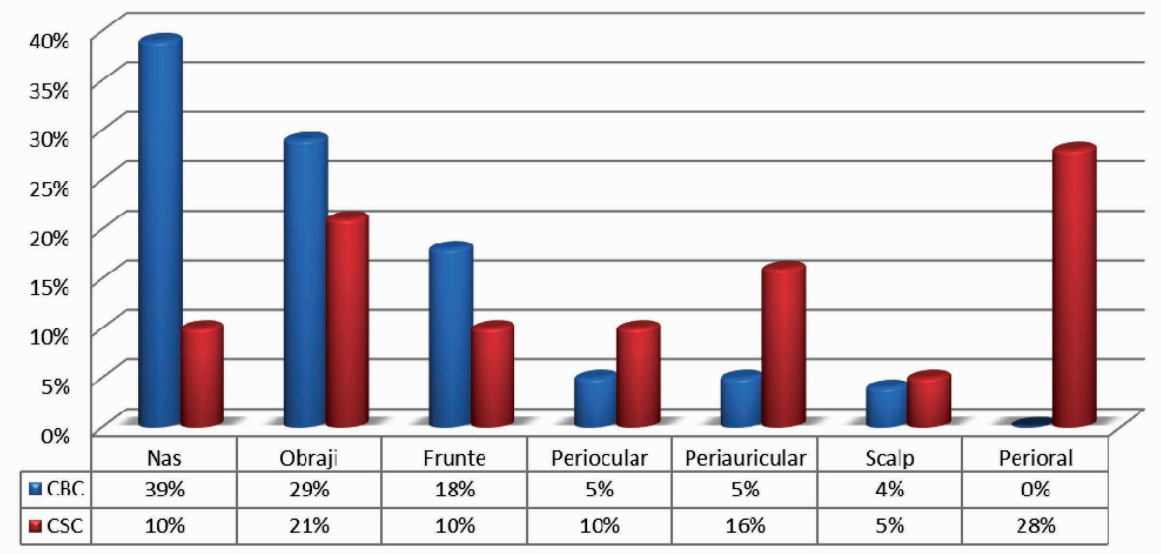

FIGURA 5. Repartiția pacienților după localizarea leziunilor la nivelul extremității cefalice

velul nasului, reprezentând 39\% din total. A doua localizare a fost zona obrajilor, în proporție de $29 \%$, urmată de frunte (18\%). În regiunea periauriculară și în cea perioculară s-au localizat 5\% dintre leziuni, iar la nivelul scalpului - 4\% dintre leziuni. $\mathrm{Nu}$ s-a înregistrat niciun caz de carcinom bazocelular, în lotul studiat, cu localizare periorală.
În contrast cu distribuția carcinoamelor bazocelulare la nivelul capului, carcinoamele spinocelulare s-au situat majoritar în regiunea periorală, în proporție de $38 \%$. Zona obrajilor reprezintă a doua localizare, reprezentând $28 \%$ din total. Următoarele zone de distribuție a leziunilor de carcinom spinocelular, în ordinea frecvenței, au fost regiunea 
periauriculară (16\%), regiunea perioculară $(10 \%)$, frunte $(10 \%)$, nas $(10 \%)$. Cele mai puține leziuni, în lotul studiat, s-au înregistrat la nivelul scalpului.

$45 \%$ dintre cazurile diagnosticate cu CSC au avut un grad de diferențiere înalt (G1), același număr de cazuri a fost încadrat în gradul G2, iar 10\% dintre cazuri au prezentat un grad intermediar-înalt de diferențiere (G1-G2). În lotul studiat, nu s-au înregistrat cazuri de CSC cu un grad de diferențiațiere scăzut precum G3 sau G4.

Din punctul de vedere al formei clinice, cel mai întâlnit tip de carcinom bazocelular în lotul studiat a fost cel nodular, în procent de $75 \%$, localizat cel mai des la nivelul extremității cefalice. CBC superficial a prezentat următoarea distribuție topografică în ordinea frecvenței leziunilor: trunchi, extremitate cefalică, membre. În cazurile de CBC infiltrativ, leziunile au fost localizate la nivelul capului și trunchiului.

\section{DISCUŢII}

Carcinomul bazocelular şi cel spinocelular alcătuiesc categoria cancerelor de piele nonmelanocitare și sunt cel mai frecvent diagnosticate cancere la nivel mondial.

Lotul studiat este alcatuit din 140 de pacienți care au primit diagnosticul de neoplasm malign nonmelanocitar C44 conform ICD-10. În urma consultului dermatologic, $84 \%$ dintre aceștia $(n=$ 118) au primit diagnosticul clinic prezumtiv de CBC și doar $12 \%(n=17)$ pe cel de CSC. Predominanța marcată a cazurilor de $\mathrm{CBC}$ este în concordanță cu datele din literatură referitoare la incidența cazurilor de CBC comparativ cu cele de CSC. Societatea Americană pentru Cancer (ACS) raportează că anual sunt diagnosticate 5,4 milioane de cazuri de carcinoame cutanate bazocelulare și spinocelulare, $80 \%$ dintre acestea fiind CBC (5).

Examenul histopatologic, care asigură diagnosticul de certitudine, a confirmat diagnosticul de CBC în 76\% dintre cazuri și pe cel de CSC în 58\% dintre cazuri. La 8 dintre pacienți, suspiciunea clinică a fost de $\mathrm{CBC}$, dar, după realizarea examenului HP, diagnosticul final a fost de CSC.

Vârsta minimă de diagnostic a carcinomului bazocelular înregistrată în cadrul pacienților studiați a fost de 37 de ani, vârsta maximă de 94

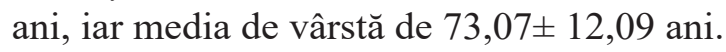

Aceste date referitoare la vârstă se corelează cu cele citate în literatura de specialitate, CBC fiind o tumoare a cărei incidență crește cu vârsta pacientului. Acest fapt se datorează, pe de-o parte, efectului cumulativ al radiațiilor UV, cunoscut factor impli- cat în etiopatogenia carcinoamelor cutanate nonmelanocitare. Pe de altă parte, sunt implicate reducerea densității melanocitelor cutanate și alterarea funcției și reducerea numărului de limfocite $\mathrm{T}$ o dată cu înaintarea în vârstă (7).

În cadrul lotului descris în studiu, prevalența maximă a fost observată la grupele de vârstă din intervalul 70-79 ani (38,04\%). Există studii care indică că incidența CBC este mult crescută (de peste 100 de ori) în grupa de vârstă 55-70 de ani decât la cei de 20 de ani sau mai tineri. Cel mai frecvent sunt afectate persoanele cu vârsta între 50 și 80 de ani. Cu toate acestea, CBC se poate dezvolta și la adolescenți, iar aproximativ 5 până la 15\% dintre cazurile de CBC apar la pacienții cu vârsta cuprinsă între 20 și 40 de ani. Tipurile CBC cu creștere agresivă sunt mai frecvent observate la pacienții cu vârsta mai mică de 35 de ani decât la persoanele în vârstă (5).

Vârsta tipică la prezentare pentru CSC, citată în literatură, este de aproximativ 70 de ani, dar poate varia însă foarte mult în anumite grupuri cu risc ridicat (destinatarii transplantului de organe, pacienții cu epidermoliză buloasă), CSC manifestându-se adesea la o vârstă mult mai mică. În cadrul lotului descris în studiu, prevalenţa maximă poate fi observată la grupa de vârstă cuprinsă în intervalul 80-89 ani (50\%). Rezultatul obținut poate fi atribuit expunerii cumulate de-a lungul vieții la RUV, creșterii mediei de vârstă și examinărilor cutanate mai frecvente.

La cei 140 de pacienți, au predominant cazurile cu o singură leziune (94\%). Există 6 cazuri cu 2 leziuni (4\%), în timp ce leziuni multiple care îmbracă aspectul de carcinomatoză bazocelulară au fost prezente la 3 pacienți ( $2 \%)$. Studii efectuate în trecut au arătat un număr mediu de 1,3-1,7 tumori per pacient, iar procentul pacienților cu mai mult de o leziune variază de la 6.6 la $32 \%$ (8). Riscul de a dezvolta o nouă leziune de $\mathrm{CBC}$ la un pacient diagnosticat anterior cu $\mathrm{CBC}$ este de 10 ori mai mare decât în populația generală (9).

În literatură se raportează zonele fotoexpuse drept localizare de elecție pentru tumorile cutanate nonmelanocitare, cel mai frecvent implicată fiind extremitatea cefalică, $80 \%$ dintre tumori dezvoltându-se la nivelul feței, dintre care 30\% în regiunea nasului, ceea ce demonstrează rolul radiațiilor UV în apariţia carcinoamelor cutanate (10). Totuşi, au fost raportate și cazuri dezvoltate la nivelul regiunilor genitale, ariilor mamelonare, axilelor, periombilical, ariilor interdigitale (11-13).

Analizând rezultatele, am observat că, în lotul studiat, localizarea cea mai frecventă a tumorilor a 
fost la nivelul capului (74\%), urmată de trunchi (24\%). Deşi membrele primesc o cantitate mult mai mare de radiații solare decât trunchiul, doar $2 \%$ dintre tumori sunt localizate la nivelul membrelor, fapt ce sugerează o etiopatogenie multifactorială. Unul dintre cei mai importanți factori ar putea fi fototipul cutanat al fiecărui pacient, persoanele cu pielea deschisă la culoare fiind mult mai predispuse la dezvoltarea unui carcinom bazocelular sau spinocelular decât persoanele cu cantitate crescută de melanină, aceasta având rol protectiv împotriva RUV.

Cele mai multe leziuni de carcinom bazocelular de la nivelul extremității cefalice s-au situat la nivelul nasului, reprezentând $35 \%$ din total. $\mathrm{Nu}$ s-a înregistrat niciun caz de carcinom bazocelular, în lotul studiat, cu localizare periorală. Rezultatele obținute sunt în concordanță cu cele ale unui studiu efectuat pe 300 de cazuri de CBC, în Brazilia pe o perioadă de 4 ani (14).

În contrast cu distribuția carcinoamelor bazocelulare la nivelul capului, carcinoamele spinocelulare s-au situat majoritar în regiunea periorală, în proporție de $38 \%$, aceste date fiind similare cu rezultatele unui studiu care a urmărit distribuția leziunilor CBC și CSC în funcție de unitatea facială estetică (15).

Conflict of interest: none declared

Financial support: none declared

\section{BIBLIOGRAFIE}

1. Lăcraru $A E$, Creţu S, Țiplica GS, Sălăvăstru CM. Artificial UV Exposure: What are The Risks? RoJCED. 2015; 2(2):92-94.

2. Cancer Facts and Figures (2016). American Cancer Society. Available at: http://www.cancer.org/acs/groups/content/@research/ documents/document/acspc-047079.pdf.

3. http://www.who.int/uv/faq/skincancer/en/index1.html.

4. Lazovich D, Choi K, Vogel RI. Time to get serious about skin cancer prevention. Cancer Epidemiol Biomarkers Prev. 2012 Nov;21(11):1893-901.

5. Bader RS, James WD, Basal Cell Carcinoma. Available at: http:// emedicine.medscape.com /article/276624.

6. Spence JM. Actinic Keratosis. Medscape. Available at: http:// emedicine.medscape.com/ article/1099775.

7. Syrigos KN, Tzannou I, Katirtzoglou N, Georgiou E. Skin cancer in the elderly. In Vivo. 2005 May-Jun;19(3):643-52.

8. Naldi L, DiLandro A, D'Avanzo B, Parazzini F. Host-related and environmental risk factors for cutaneous basal cell carcinoma: evidence from an Italian case-control study. J Am Acad Dermatol. 2000 Mar;42(3):446-52.

9. Marcil I, Stern RS. Risk of developing a subsequent nonmelanoma skin cancer in patients with a history of nonmelanoma skin cancer: a critical review of the literature and meta-analysis. Arch Dermatol. 2000 Dec;136(12):1524-30.

\section{CONCLUZII}

Numărul cazurilor de CBC a fost considerabil mai mare decât cel de CSC. Se observă predominanța pacienților de sex masculin atât în rândul pacienților diagnosticați cu CBC cât și la cei cu CSC. În majoritatea cazurilor, leziunile au fost unice, au existat cazuri cu leziuni duble, dar și leziuni multiple cu aspect de carcinomatoză bazocelulară, ceea ce justifică necesitatea unei evaluări periodice a persoanelor $\mathrm{cu}$ antecedente de CBC. Toate cazurile de CSC au prezentat un grad înalt de diferențiere (G1-G2). Cel mai des întâlnită formă clinică de CBC la pacienții din lotul studiat a fost forma nodulară, iar cel mai puțin întâlnită a fost cea infiltrativă. Leziunile de CBC nodular și infiltrativ s-au situat la nivelul extremităţii cefalice, iar cele mai multe leziuni superficiale s-au situat la nivelul trunchiului.

Se evidențiază necesitatea mai multor studii pentru aplicarea unei prevenții și a unui management corespunzător începând de la medicul de familie până la specialist. Profilaxia şi diagnosticul precoce sunt esenţiale în patologia tumorală cutanată, contribuind la creşterea supravieţuirii şi la îmbunătăţirea calităţii vieţii şi a prognosticului.

10. Chinem VP, Miot HA. Epidemiology of basal cell carcinoma. An Bras Dermatol. 2011 Mar-Apr;86(2):292-305.

11. Lin CT, Chen SG, Chen TM, Chang SC. Axillary basal cell carcinoma: case report and literature review. Acta Dermatovenerol Croat. 2011;19(2):107-9.

12. Bordel Gómez MT, Sánchez Estella J, Cardeñoso Alvarez E, Santos Durán JC, Román Curto $\mathrm{C}$. Basocellular cancer of the vulva: a rare location for one of the most frequent types of skin cancer. Actas Dermosifiliogr. 2006 Jul-Aug;97(6):415-6.

13. Redondo Martínez E, López AR, Cruz Benavides F, Camacho Galán R. Basal cell carcinoma of the scrotum. A rare localization linked to a bad prognosis. Arch Esp Urol. 2000 Sep;53(7):642-4.

14. Gomides MD, Berbert AL, Mantese SA, Rocha A, Ferreira MS, Borges AS. Skin diseases in patients with AIDS: study in 55 cases in Uberlândia, MG, Brazil. Rev Assoc Med Bras (1992). 2002 Jan-Mar;48(1):36-41.

15. Choi JH, Kim YJ, Kim H, Nam SH, Choi YW. Distribution of Basal cell carcinoma and squamous cell carcinoma by facial esthetic unit. Arch Plast Surg. 2013 Jul;40(4):387-91. 